\title{
Cryptic diversity among Yazoo Darters (Percidae: Etheostoma raneyi) in disjunct watersheds of northern Mississippi
}

\author{
Ken A. Sterling ${ }^{\text {Corresp., }}{ }^{\text {, }}$, Stuart V. Nielsen ${ }^{2}$, Andrew J. Brown ${ }^{3}$, Melvin L. Warren, Jr. ${ }^{1}$, Brice P. Noonan ${ }^{4}$ \\ ${ }^{1}$ USDA Forest Service, Southern Research Station, Stream Ecology Laboratory, Oxford, Mississippi, United States of America \\ 2 Division of Herpetology, Florida Museum of Natural History, Gainesville, Florida, United States of America \\ 3 Louisiana Purchase Gardens and Zoo, Monroe, Louisiana, United States of America \\ 4 Department of Biology, University of Mississippi, University, Mississippi, United States \\ Corresponding Author: Ken A. Sterling \\ Email address: kenneth.a.sterling@usda.gov
}

The Yazoo Darter, Etheostoma raneyi (Percidae), is an imperiled freshwater fish species endemic to tributaries of the Yocona and Little Tallahatchie rivers of the upper Yazoo River basin, in northern Mississippi, USA. The two populations are allopatric, isolated by unsuitable lowland habitat between the two river drainages. Relevant literature suggests that populations in the Yocona River represent an undescribed species but a lack of data prevents a thorough evaluation of possible diversity throughout the range of the species. Our goals were to estimate phylogenetic relationships of the Yazoo Darter across its distribution and identify cryptic diversity for conservation management purposes. Maximum likelihood (ML) phylogenetic analyses of the mitochondrial cytochrome $b$ (cytb) gene returned two reciprocally monophyletic clades representing the two river drainages with high support. Bayesian analysis of cytb was consistent with the ML analysis but with low support for the Yocona River clade. Analyses of the nuclear S7 gene yielded unresolved relationships among individuals in the Little Tallahatchie River drainage with mostly low support, but returned a monophyletic clade for individuals from the Yocona River drainage with high support. No haplotypes were shared between the drainages for either gene. Additional cryptic diversity within the two drainages was not indicated. Estimated divergence between Yazoo Darters in the two drainages occurred during the Pleistocene ( $<1$ million years ago) and was likely linked to repeated spatial shifts in suitable habitat and changes in watershed configurations during glacial cycles. Individuals from the Yocona River drainage had lower genetic diversity consistent with the literature. Our results indicate that Yazoo Darters in the Yocona River drainage are genetically distinct and that there is support for recognizing Yazoo Darter populations in the Yocona River drainage as a new species under the unified species concept. 
1 Cryptic diversity among Yazoo Darters (Percidae: Etheostoma raneyi) in 2 disjunct watersheds of northern Mississippi

3

4 Ken A. Sterling ${ }^{1 *}$, Stuart V. Nielsen ${ }^{2}$, Andrew J. Brown ${ }^{3}$, Melvin L. Warren, Jr. ${ }^{1}$, and Brice P.

5 Noonan $^{4}$

6

7 IUSDA Forest Service, Southern Research Station, Stream Ecology Laboratory, 1000 Front

8 Street, Oxford, MS 38655, USA

$9 \quad{ }^{2}$ Florida Museum of Natural History, Division of Herpetology, 1659 Museum Road, Gainesville, $10 F L 32611$, USA

${ }^{3}$ Louisiana Purchase Gardens and Zoo, 1405 Bernstein Park Rd., Monroe, LA 71202, USA

${ }^{4}$ Department of Biology, University of Mississippi, Box 1848, University, MS 38677, USA 
25

26

27

28

29

30

\section{Introduction}

The southeastern United States has a globally significant amount of diversity among its freshwater fishes (Abell et al., 2008). A large portion of this diversity is contained within Etheostomatinae (Percidae), the darters (Jelks et al., 2008; Page \& Burr, 2011). Though the group shows a wide variety of life history strategies and associated distributional patterns (Fluker, Kuhajda \& Harris, 2014), many species of darters are range-limited (microendemics) (Page, 1983; Page \& Burr, 2011) and share a suite of life history characteristics that are associated with limited dispersal (Turner \& Trexler, 1998; Turner, 2001), including niche conservatism (Keck \& Near, 2010). The discovery of microendemism in darters is occurring more frequently because, at least in part, the routine use of genetic tools is increasingly uncovering cryptic diversity (Hollingsworth \& Near, 2009; April et al., 2011; Echelle et al., 2015; Kozal et al., 2017; Matthews \& Turner, 2019).

The Yazoo Darter (Etheostoma raneyi Suttkus and Bart, 1994) is a snubnose darter (clade Adonia, sensu Near et al., 2011) distributed in the upper Yazoo River basin in north-central Mississippi (Figs. 1, 2, S1, S2, and S3). Surface geology mostly comprises highly erodible, unconsolidated sands and clays with resulting fine substrates within streams. Topography is relatively flat compared with upland regions but is more variable compared with the Lower Gulf Coastal Plain and Mississippi Alluvial Plain to the west (Ross, 2001; Keck \& Etnier, 2005; Powers \& Warren, 2009) (Fig. 1).Yazoo Darters occur in headwater tributaries of the Little Tallahatchie (L.T.R.) and Yocona (Y.R.) rivers whose confluence lies in bottomland habitat of the Mississippi Alluvial Plain, which is unfavorable for the darter. In common with other snubnose darters, Yazoo Darters are small ( $<65 \mathrm{~mm}$ Standard Length), benthic insectivores 
47 lacking a swim bladder (Page, 1983; Johnston \& Haag, 1996; Sterling, Warren \& Henderson, 48 2013). Long distance movements for spawning or feeding are not documented for snubnose darter species. Larvae of snubnose darters, including the Yazoo Darter, are pelagic but active swimmers upon hatching and select for sheltered areas out of direct current immediately downstream of spawning areas; passive drift of larvae is not documented (Simon \& Wallus, 2006; Ruble, Sterling \& Warren, 2019). A population genetic study of the Yazoo Darter using microsatellite data indicated limited historical dispersal among tributary streams and virtually no contemporary dispersal, likely because of anthropogenic habitat destruction (Warren et al., 2002; Sterling et al., 2012). Genetic structure was high across small spatial scales among some tributary populations $\left(\mathrm{F}_{\mathrm{st}}=0.03-0.17\right)$ within each major drainage where the species occurs (L.T.R. and Y.R.) and was also high between drainages $\left(\mathrm{F}_{\mathrm{st}}=0.17-0.29\right)$ (Sterling et al., 2012). A phylogenetic analysis of Upper Gulf Coastal Plain snubnose darters (Etheostoma pyrrhogaster, E. cervus, and E. raneyi, see Fig. 1) in western Kentucky, Tennessee, and northern Mississippi indicated that Yazoo Darters inhabiting the L.T.R. and Y.R were genetically distinct and reciprocally monophyletic with high posterior support. Powers and Warren (2009) suggested that the same vicariant events isolated all forms of darters they examined in the Upper Gulf Coastal Plain. However, the study was limited to six Yazoo Darters from only a few streams in each drainage $(\mathrm{n}=12)$ (Powers \& Warren, 2009).

The Yazoo Darter is categorized as vulnerable by the American Fisheries Society (Jelks et al., 2008) and the Southeastern Fishes Council (Warren et al., 2000), as globally imperiled by the Nature Conservancy (NatureServe, 2019), as sensitive by the USDA Forest Service (USDA Forest Service, 2013), and as a Tier 1 species of greatest conservation need by the Mississippi State Wildlife Action Plan (Mississippi Museum of Natural Science, 2015). Human-assisted 
gene flow among tributaries within each drainage was recommended as a conservation management action (Sterling et al., 2012). Even so, an investigation of possible cryptic diversity across the species' distribution within each drainage as well as estimates of genetic structure using markers reflecting deeper evolutionary relationships is needed to better inform such an action. We used genetic sequences from mitochondrial cytb and nuclear $S 7$ genes, to 1) investigate possible cryptic diversity within and between each major drainage; 2) estimate phylogenetic relationships among populations within each drainage to inform discussion of human-assisted gene flow for conservation management; and 3) to assess the results from Powers \& Warren (2009) using larger sample sizes from sites across the distribution of the species.

\section{Materials and Methods}

We sampled 117 individuals from 20 streams representative of the entire range of the Yazoo Darter via single-pass backpack electrofishing, dip nets, and seines. Collecting localities included nine streams in the Y.R. drainage and 11 streams in the L.T.R. drainage (Fig. 2; Tables 1, S1, and S2). We obtained tissue samples by either taking pelvic fin clips or by collecting voucher specimens, which we stored in $95 \%$ ethanol at $-74^{\circ} \mathrm{C}$. This study was conducted with the approval of the University of Mississippi IACUC Committee (protocol 09-027), using annual collection permits issued to us from the Mississippi Museum of Natural Science (2009-2017: 0604091, 0513101, 0624112, 0622122, 0602132, 0610142, 0624151, 0715163, 1010173).

We isolated whole genomic DNA (MacManes, 2013) and used previously published PCR primers to amplify the entire mitochondrial cytb gene (1140 bp; Song et al., 1998) and the forward sequence of intron 1 of the nuclear $S 7$ ribosomal gene (599 bp; Chow \& Hazama, 1998). 
93 PCR components were as follows: $9.8 \mu 1 \mathrm{ddH}_{2} \mathrm{O}, 0.2 \mu \mathrm{dNTP}, 0.4 \mu 1 \mathrm{MgCl}_{2}, 2 \mu 15 \mathrm{x}$ reaction

94 buffer, $0.2 \mu 1$ each $10 \mathrm{nM}$ primer, $0.15 \mu 1$ Phire $^{\mathrm{TM}} \mathrm{Taq}$, and $1.5 \mu 1$ of template DNA $(\sim 15 \mu 1$ total

95 reaction volume). We set conditions for PCR reactions as $98^{\circ} \mathrm{C}$ for $30 \mathrm{~s}$, followed by 30 cycles

96 of $98^{\circ} \mathrm{C}$ for $6 \mathrm{~s}, 53.1-56^{\circ} \mathrm{C}$ for $30 \mathrm{~s}$, and $72^{\circ} \mathrm{C}$ for $60 \mathrm{~s}$. We purified and sequenced PCR

97 products using ExoSAP-IT (ThermoFisher Scientific) and Big Dye (ver. 3.1, ThermoFisher

98 Scientific) according to manufacturer's recommendations. Arizona State University DNA

99 sequencing facility processed the samples

100 (https://asu.corefacilities.org/service_center/show_external/3900/asu-dna-lab) using an

101 automated ABI 3730 sequencer. We assembled all resulting forward and reverse sequences into

102 contigs for each individual and aligned them using MEGA (ver. 7.0.26; Kumar, Stecher \&

103 Tamura, 2016). We obtained outgroup sequence data and sequences for two additional Yazoo

104 Darters (Near et al., 2011), one from each major drainage, from GenBank for use in our analyses.

105 Sequence data for this study are available from GenBank

106 (https://www.ncbi.nlm.nih.gov/nuccore/) and Dryad (XXXX) (Tables S1, S2, and S3).

107 Data from $c y t b$ and $S 7$ could not be combined into a single concatenated analysis because the 108 data were not derived from the same set of individuals (Matthews \& Turner, 2019). We used

109 PartitionFinder V 1.1.1 (Lanfear et al., 2012) to find the best-fit model for each locus. The cytb

110 dataset was partitioned by $1^{\text {st }}, 2^{\text {nd }}$, and $3^{\text {rd }}$ codon positions, and the $S 7$ dataset was analyzed as a

111 single partition. We analyzed partitioned datasets for each gene (Tables S1, and S2) using

112 Bayesian Inference (BI) implemented in MrBayes ver. 3.2.6 (Ronquist et al., 2012) via CIPRES

113 Science Gateway ver. 3.3 (https://www.phylo.org/) (Miller et al., 2010). Each partition/analysis

114 included the most appropriate substitution models for the two loci as suggested by

115 PartitionFinder. We used two runs of MrBayes for $10^{6}$ generations; four Markov chains sampled 
116 every 10,000 steps and Tracer (ver. 1.7.1; Rambaut et al., 2018) removed 25\% of the posterior

117 trees as burn-in. We then generated a 50\% majority rule consensus tree in MrBayes. We used the

118 same data to construct Maximum Likelihood (ML) trees using RAxML-HPC ver. 8.0

119 (https://cme.h-its.org/exelixis/web/software/raxml/) (Stamatakis, 2014) also using the CIPRES

120 Science Gateway ver. 3.3 (Miller et al., 2010). We used the default GTR model and performed

121100 bootstrap replicates to assess nodal support. We considered nodes with posterior

122 probabilities $\geq 95 \%$ as strongly supported (Huelsenbeck \& Ronquist, 2001).

123 We visualized relationships among individuals using haplotype networks (TCS v. 1.21;

124 Clement et al., 2000) for each gene. We estimated uncorrected pairwise genetic distances (pdistances) using MEGA ver. 7.0.26 (Kumar, Stecher \& Tamura, 2016) between drainages and

126 among watersheds within drainages for each gene. For comparison, we also generated p-

127 distances among all snubnose darters (clade Adonia, sensu Near et al., 2011) using our data and 128 publicly available $c y t b$ genetic sequences (see Table S4 for genetic sequence data).

129 We calculated the number of haplotypes, and haplotype diversity for both loci using DNAsp

V 5.10 (Librado \& Rozas, 2009) between drainages and among watersheds within drainages. We calculated estimates of divergence times using rates of molecular evolution for the $c y t b$ $(1.8 \% / \mathrm{my})$ and $S 7(0.34 \% / \mathrm{my})$ genes reported by Near et al. (2011), and our observed genetic distance values produced by MEGA.

\section{Results}

136 The most appropriate substitution models for the $1^{\text {st }}, 2^{\text {nd }}$, and $3^{\text {rd }}$ codon positions of the $c y t b$ 137 (1139 nucleotides (nt) in length) were F81, GTR+G, and K80+I and for the $S 7$ gene (530 nt), 138 F81+G. Results from Bayesian and ML analyses for $c y t b$ indicate two monophyletic clades 
139 congruent with the two river drainages (Figs. 3, 4, S4, and S5). Support for reciprocally

140 monophyletic clades was high for the ML analysis (bootstrap support: Y.R., 95\%; L.T.R.,

141 100\%), but only weakly supported for the Bayesian analysis (posterior probabilities: Y.R., 0.12;

142 L.T.R., 1.0). Results from the $S 7$ data (Figs. 5, 6, S6 and S7) indicated weakly supported and

143 inconsistent phylogenetic relationships among individuals from the L.T.R. drainage, though

144 samples from the Y.R. drainage composed a single clade with high support (95\% bootstrap

145 support and 0.97 posterior probability). Haplotype networks for $S 7$ and $c y t b$ indicate that no

146 haplotypes were shared between drainages (Fig. 7). A total of fifteen genetic characters from

147 both genes are diagnostic of Yazoo Darters in the two major river drainages (Table 2).

148 Uncorrected p-distances for Yazoo Darters $(c y t b)$ between drainages were $0.8 \%$ and among

149 watersheds within drainages was $0.01 \%$ in the Y.R. drainage and 0.1 and $0.11 \%$ in the L.T.R.

150 drainage (Table 3). For comparison, p-distances (cytb) among other snubnose darters ranged

151 from 0.5-14.53\% (Tables 4-S5). P-distances for Yazoo Darters (S7) between drainages were

$1520.3 \%$ and among watersheds within drainages were $0.01 \%$ in the Y.R. drainage and ranged from

$153 \quad 0.07-0.17 \%$ in the L.T.R. drainage (Table 3).

154 Haplotype diversity was higher in the L.T.R. drainage (cytb: Hd = 0.66, 11 haplotypes; $S 7: \mathrm{Hd}$ $155=0.48,2$ haplotypes) than in the Y.R. drainage (cytb: $\mathrm{Hd}=0.11,3$ haplotypes; $S 7: \mathrm{Hd}=0.06,2$

156 haplotypes). Estimated times of divergence were 0.88 (S7) and 0.44 my (cytb).

157

158 Discussion

159 Our results indicate, 1) there is no evidence of cryptic diversity within each major river 160 drainage; 2) genetic diversity is lower in the Y.R. drainage relative to the L.T.R. drainage; 3)

161 consistent with the results from Powers \& Warren (2009), there is support for recognizing Yazoo 
162 Darter populations in the Y.R. drainage as a distinct species under the unified species concept

163 (De Queiroz, 2007); 4) Our estimates of time of divergence are similar to estimates for closely

164 related snubnose darter species in Tennessee and Kentucky (Kozal et al., 2017), which supports

165 the proposal in Powers \& Warren (2009) that the same vicariant events led to a late Pleistocene

166 species radiation among snubnose darters in western Tennessee and Kentucky and northern

167 Mississippi.

168 Though the lack of genetically distinct clades within drainages was not a surprise, the lack of

169 a clear and consistent link between genetic clades and geography within drainages was

170 unexpected (Figs. 2, S4-S7). Though samples from watersheds within drainages show a weak to

171 moderate tendency to be grouped within clades (e.g., Cypress Creek, Tippah River, Otoucalofa

172 Creek), the low support at most within-drainage nodes (phylogenetic trees) indicates that the

173 only inference that can be made with any confidence is that our data did not reveal genetically

174 distinct populations or cryptic diversity within either drainage. In contrast, microsatellite markers

175 indicated that tributaries do contain genetically distinct populations with a strong isolation by

176 distance effect (Sterling et al., 2012). This is explained by higher mutation rates among

177 microsatellite markers and, to some extent, the effects of human habitat alteration and

178 consequent isolation. Taken together, patterns of gene flow within drainages apparently have not

179 been stable over enough generations to show a clear relationship between watersheds and genetic 180 subclades in the $c y t b$ and $S 7$ data.

181 Our results show that genetic divergence and diversity is much lower in the Y.R. drainage 182 than in the L.T.R. drainage (Table 4; Fig. 7). Genetic distances between Otoucalofa Creek and 183 the Y.R. are an order of magnitude lower that the distances between Cypress Creek and the 184 Tippah River, for example (Fig. 2), and the haplotype network results (Fig. 7) clearly show less 
185

186

187

188

189

190

191

192

193

194

195

196

197

198

199

200

201

202

203

204

205

206

207

genetic diversity in the Y.R. drainage. Lower divergence can be explained by the difference in area of distribution of the Yazoo Darter between the two drainages (Fig. 2). Smaller area of distribution in the Y.R. drainage (smaller watersheds with fewer and smaller streams) would likely result in greater gene flow, lower divergence, and less genetic diversity (Frankham 1996). Another possible explanation for lower diversity in the Y.R. drainage is a founder effect, though our results are not consistent with this explanation (e.g., stochastic processes likely would have resulted in greater divergence between drainages than we observed) and do not indicate any mechanism for such an explanation (e.g., stream capture). The lower genetic diversity observed in the Y.R. drainage is consistent with previous genetic studies (Powers \& Warren, 2009;

Sterling et al., 2012). Our results and the low effective population sizes reported in Sterling et al. (2012) indicate that human-assisted gene flow is warranted.

Genetic distances between drainages were low, but are comparable to other closely related snubnose darters (Tables 3, 4, S5). This is especially true for the Bandfin Darter group (Etheostoma zonistium, E. cervus, E. pyrrhogaster, and E. cf. zonistium). Similar genetic distances are almost certainly linked to the similar estimates for times of divergence among these taxa, which are recent (Kozal et al. 2017). Our observed distances are also similar to those reported for other sister species pairs of fishes (Johns \& Avise, 1998).

$$
\text { The lack of resolution and consistency in phylogenetic clades showing relationships in the }
$$

L.T.R. drainage using the $S 7$ marker (Figs. 5,6 ) is not surprising because in young clades of darters $c y t b$ usually has more power to resolve relationships with higher support relative to nuclear genetic markers with slower mutation rates and higher effective population sizes (Avise, 2004; Keck \& Near, 2008). The lack of resolution for the $S 7$ results is consistent with other studies (Keck \& Near, 2010; Echelle et al., 2015; Kozal et al., 2017) (Fig. 1). Even so, the S7 
208

209

210

211

212

213

214

215

216

217

218

219

220

221

222

223

224

225

226

227

228

229

230

analyses did support a monophyletic clade for samples from the Y.R. drainage, and this might be explained by smaller populations in a smaller watershed as outlined earlier when discussing relative levels of genetic divergence and diversity.

Our results using cytb did produce consistent phylogenetic trees with monophyletic clades for each drainage. However, support for the monophyly of the Y.R. clade using Bayesian analysis was weak, which is odd considering the high support for the ML and $S 7$ analyses. The low support for this clade has no apparent biological explanation. Even so, the $S 7$ and $c y t b$ results indicate recent divergence between Yazoo Darter populations in the L.T.R. and Y.R. drainages. Divergence is supported by the lack of evidence for gene flow between the drainages, even for the samples from Deer Creek which are closest to the confluence of the L.T.R. and Y.R. drainages (Fig.2). No haplotypes were shared between drainages, and all individuals sorted into clades consistent with the drainages from which they were sampled for all phylogenetic trees (Figs. S4, S5, S6 and S7). This is consistent with the literature (Powers \& Warren, 2009; Sterling et al., 2012).

The vicariant events and mechanisms that led to isolation of ancestral populations and ensuing divergence among Upper Gulf Coastal Plain snubnose darters currently recognized as E. cervus, E. pyrrhogaster, and E. zonistium almost certainly were a factor in divergence of ancestral Yazoo Darters in the upper Yazoo River basin (Powers \& Warren, 2009; Kozal et al., 2017) (Fig. 1). This is based on similar estimated times of divergence among these closely related fishes, as well as similar surface geology, topography, and watershed configurations among them (Warren et al., 2002; Keck \& Etnier, 2005; Powers \& Warren, 2009; Smith et al., 2009; Near et al., 2011; Kozal et al., 2017). Though we restrict our discussion to the Yazoo Darter, we believe that our interpretations are generally applicable to these other species. We propose that spatial shifts in 
231 suitable habitat for Yazoo Darters during repeated glacial cycles over the last 2 my led to the

232 isolation of populations in the upper Y.R. and L.T.R. drainages (see Hewitt, 1996). During

233 glacial periods and low sea levels, suitable habitat for Yazoo Darters would have expanded

234 downstream, perhaps into the present Mississippi Alluvial Plain when sea levels were at their

235 lowest (90-140 m below present). Streams were smaller (less precipitation), may have been

236 entrenched in bedrock, and had higher gradients, coarse substrate, and cold, clear water. During

237 interglacial periods sea levels rose, streams had more water, gradients moderated, stream valleys

238 filled in with fines, and streams were no longer confined to bedrock. Suitable habitat for Yazoo

239 Darters would have moved upstream.

240 As suitable habitat shifted up- and downstream in the Yazoo River Basin, connectivity among

241 groups of Yazoo Darters in tributary streams would also have changed. During interglacial

242 periods when streams were not confined to bedrock, changes in stream configurations seem more

243 likely, especially in headwaters. However, during glacial periods, streams were smaller (climate

244 was much drier) and confluences lower in the watershed were less likely to be barriers to

245 dispersal because they were smaller and may have been suitable habitat for Yazoo Darters.

246 Dispersal among tributaries under these conditions seems more likely (Fisk, 1944; Rittenour,

247 Blum \& Goble, 2007; Past Interglacials Working Group of PAGES, 2016).

248 Spatial changes in the downstream extent of suitable habitat likely interacted with changes in

249 the location of the ancient confluence of the Y.R. and L.T.R. to isolate Yazoo Darter

250 populations. Reliable data exists for estimating the number, duration, and timing of glacial and

251 interglacial periods over about the last 800,000 years (Past Interglacials Working Group of

252 PAGES, 2016). An estimated 11 cycles between glacial and interglacial periods are identified.

253 Estimated duration of interglacial periods is much shorter (166,700 years) than glacial and 
254 transitional periods (633,300 years) (Fisk, 1944; Past Interglacials Working Group of PAGES,

255 2016). Given this setting, downstream connectivity among demes would have likely had greater

256 influence structuring Yazoo Darter populations between the two major drainages than possible

257 shifts in stream configurations. Further, changes to the position of the confluence of the L.T.R.

258 and Y.R. and with the ancient predecessors of the Ohio and Yazoo rivers were likely

259 instrumental in the phylogenetic pattern seen in our results (see text and figures in Fisk, 1944;

260 Fig. 1). It seems apparent that at some point (about 0.4-0.8 my) suitable habitat for Yazoo

261 Darters no longer encompassed the confluence of the Y.R. and L.T.R. during glacial periods.

262 Our results help to refine the management actions (i.e., human-assisted gene flow) suggested

263 in Sterling et al. (2012). Phylogenetic trees show a weak to moderate association between

264 watersheds and clades within drainages, though we did not find clear evidence of genetically

265 distinct groups that were consistent with geography (e.g., management units to guide human-

266 assisted gene flow) (Figs. S4-S7). Even so, based on our results and those in Sterling et al.

267 (2012), we recommend relocation of individuals among tributaries that are closest together

268 within watersheds as categorized in Sterling et al. (2012). Within the Y.R. watershed we

269 recommend restricting movement of individuals to within the Otoucalofa Creek watershed or

270 adjacent tributaries to the mainstem Y.R. Since genetic diversity was higher in the L.T.R. than in

271 the Y.R., and because populations in the Y.R. face greater risks (i.e., area of distribution is much

272 smaller, estimates of effective population sizes are extremely low, there is no evidence of

273 contemporary gene flow among adjacent tributaries, streams yielding Yazoo Darters are nearly

274 all on private lands, and there is rapid urban development in this drainage, see Sterling et al.,

2752012 and 2013), human-assisted gene flow within the Yocona River should be implemented. 
276 Research aimed at identifying mechanisms of gene flow is also desperately needed for the Yazoo

277 Darter, which would also help inform management of other imperiled forms of snubnose darters.

278

279 Conclusions

280 Our results indicate that populations of the Yazoo Darter in the Y.R. drainage are genetically

281 distinct and represent a recently diverged and undescribed cryptic species of snubnose darter.

282 However, because phylogenetic evidence constitutes only one line of evidence for divergence,

283 we recommend that other lines of evidence for species delimitation under the unified species

284 concept (De Quieroz, 2007) be examined. Though there are no obvious differences in pigment

285 patterns or color between the populations in each drainage, Suttkus et al. (1994) noted modal

286 differences in lateral line scale counts and Sterling et al. (2013) showed that Yazoo Darters in the

287 Y.R. drainage are significantly longer than those in the L.T.R. drainage. Further investigation of

288 morphology, meristics, and pigment patterns is warranted.

289

290 Acknowledgments

291 We would like to thank M. Bland, Z. Barnett, A. Carson, C. Smith, B. Sterling, W. Sterling, 292 and G. McWhirter for help collecting samples. We are also grateful to J. Hubbell and J. Schaefer

293 for sharing data and G. Henderson for help with figures. Any use of trade, firm, or product

294 names is for descriptive purposes only and does not imply endorsement by the US Government. 
295

296

297

298

299

300

301

302

303

304

305

306

307

308

309

310

311

312

313

314

315

\section{Literature Cited}

Abell, R., M.L. Thieme, C. Revenga, M. Bryer, M. Kottelat, N. Bogutskaya, B. Coad, N. Mandrak, S.C. Balderas, W. Bussing, M.L.J. Stiassny, P. Skelton, G.R. Allen, P. Unmack, A. Naseka, R. Ng, N. Sindorf, J. Robertson, E. Armijo, J.V. Higgins, T.J. Heibel, E. Wikramanayake, D. Olson, H.L. Lopez, R.E. Reis, J.G. Lundberg, M.H.S. Perez \& P. Petry. 2008. Freshwater ecoregions of the world: a new map of biogeographic units for freshwater biodiversity conservation. Bioscience 58:403-414.

April, J., R.L. Mayden, R.H. Hanner \& L. Bernatchez. 2011. Genetic calibration of species diversity among North America's freshwater fishes. Proceedings of the National Academy of Sciences 108:10602-10607.

Avise, J.C. 2004. Molecular Markers, Natural History, and Evolution. Sinauer Associates, Sunderland, MA.

Chow, S. \& K. Hazama. 1998. Universal PCR primers for $S 7$ ribosomal protein gene introns in fish. Molecular Ecology 7:1255-1256.

Clement, M., D. Posada \& K.A. Crandall. 2000. TCS: a computer program to estimate gene genealogies. Molecular Ecology 9:1657-1660.

De Queiroz, K. 2007. Species concepts and species delimitation. Systematic Biology 56:879886.

Echelle, A.A., M.R. Schwemm, N.J. Lang, J.S. Baker, R.M. Wood, T.J. Near \& W.L. Fisher. 2015. Molecular systematics of the Least Darter (Percidae: Etheostoma microperca): historical biogeography and conservation implications. Copeia 103:87-98. 
316 Fisk, H.N. 1944. Geological Investigation of the Alluvial Valley of the Lower Mississippi River.

317 U.S. Army Corps of Engineers, Report to the Mississippi River Commission, Vicksburg, MS.

318 Available at: https://ngmdb.usgs.gov/Prodesc/proddesc_70640.htm. Accessed June 2019.

319 Fluker, B.L., B.R. Kuhajda \& P.M. Harris. 2014. The influence of life-history strategy on genetic

320 differentiation and lineage divergence in darters (Percidae: Etheostomatinae). Evolution

$321 \quad 68: 3199-3216$.

322 Frankham, R. 1996. Relationship of genetic variation to population size in wildlife. Conservation Biology 10:1500-1508.

324

325

326

327

328

329

330

331

332

333

334

335

336

Hewitt, G.M. 1996. Some genetic consequences of ice ages, and their role in divergence and speciation. Biological Journal of the Linnean Society 58:247-276.

Hollingsworth, Jr., P.R. \& T.J. Near. 2009. Temporal patterns of diversification and microendemism in Eastern Highland endemic Barcheek Darters (Percidae: Etheostomatinae). Evolution 63:228-243.

Huelsenbeck, J.P. \& F. Ronquist. 2001. MRBAYES: Bayesian inference of phylogenetic trees. Bioinformatics 17:754-755.

Jelks, H.L., S.J. Walsh, N.M. Burkhead, S. Contreras-Balderas, E. Diaz-Pardo, D.A. Hendrickson, J. Lyons, N.E. Mandrak, F. McCormick, J.S. Nelson, S.P. Plantania, B.A. Porter, C.B. Renaud, J.J. Schmitter-Soto, E.B. Taylor \& M.L. Warren Jr. 2008. Conservation status of imperiled North American freshwater and diadromous fishes. Fisheries 33:372-407.

Johns, G.C. \& J.C. Avise. 1998. A comparative summary of genetic distances in the vertebrates from the mitochondrial cytochrome $b$ gene. Molecular Biology and Evolution 15:1481-1490. 
337 Johnston, C.E. \& W.R. Haag. 1996. Life history of the Yazoo Darter (Percidae: Etheostoma 338 raneyi), a species endemic to north-central Mississippi. Tulane Studies in Zoology and 339 Botany 30:47-60.

340 Keck, B.P. \& D.A. Etnier. 2005. Distributional changes of the fishes of the Hatchie River system 341 in Western Tennessee and Northern Mississippi. Southeastern Naturalist 4:597-626.

342 Keck, B.P. \& T.J. Near. 2008. Assessing phylogenetic resolution among mitochondrial, nuclear, 343 and morphological datasets in Nothonotus darters (Teleostei: Percidae). Molecular Phylogenetics $344 \quad$ and Evolution 46:708-720.

345 Keck, B.P. \& T.J. Near. 2010. A young clade repeating an old pattern: diversity in Nothonotus darters (Teleostei: Percidae) endemic to the Cumberland River. Molecular Ecology 19:50305042.

348

Kozal, L.C., J.W. Simmons, J.M. Mollish, D.J. MacGuigan, E. Benavides, B.P. Keck, T.J. Near. 2017. Phylogenetic and morphological diversity of the Etheostoma zonistium species complex with the description of a new species endemic to the Cumberland Plateau of Alabama. Bulletin of the Peabody Museum of Natural History 58:263-286.

Kumar, S., G. Stecher \& K. Tamura. 2016. MEGA7: molecular evolutionary genetics analysis ver. 7.0 for bigger data sets. Molecular Biology and Evolution 33:1870-1874.

Lanfear, R., B. Calcott, S.Y.W. Ho \& S. Guindon. 2012. PartitionFinder: combined selection of partitioning schemes and substitution models for phylogenetic analyses. Molecular Biology and Evolution 29:1695-1701.

Librado, P. \& J. Rozas. 2009. DnaSP v5: a software for comprehensive analysis of DNA polymorphism data. Bioinformatics 25:1451-1452. 
359 Matthews, W.J. \& T.F. Turner. 2019. Redescription and recognition of Etheostoma cyanorum

360 from Blue River, Oklahoma. Copeia 107:208-218.

361 Miller, M.A., W. Pfeiffer \& T. Schwartz. 2010. Creating the CIPRES Science Gateway for

362 inference of large phylogenetic trees. In: Proceedings of the Gateway Computing

363 Environments Workshop (GCE), 2010, pp. 1-8. Institute of Electrical and Electronics

364 Engineers (IEEE), Washington, D.C.

365 Mississippi Museum of Natural Science. 2015. Mississippi’s State Wildlife Action Plan, 2015-

366 2025. Mississippi Department of Wildlife, Fisheries, and Parks, Jackson, Mississippi.

367 Available online at:

368

http://www.mdwfp.com/media/251788/mississippi_swap_revised_16_september_2016_red

369 uced_.pdf. Accessed October 2018.

370

MacManes. 2013. MacManes Salt Extraction Protocol. FigShare. Available at: https://doi.org/10.6084/m9.figshare.658946.v1. Accessed June 2019.

NatureServe. 2019. NatureServe Explorer: An online encyclopedia of life, ver. 7.1. NatureServe, Arlington, Virginia. Available at: http://explorer.natureserve.org. Accessed: June 2019.

Near, T.J., C.M. Bossu, G.S. Bradburd, R.L. Carlson, R.C. Harrington, P.R. Hollingsworth, B.P. Keck \& D.A. Etnier. 2011. Phylogeny and temporal diversification of darters (Percidae: Etheostomatinae). Systematic Biology 60:565-595.

Nixon, K.C. \& Q.D. Wheeler. 1990. An amplification of the phylogenetic species concept. $378 \quad$ Cladistics 6:211-223.

379 Page, L.M. 1983. Handbook of Darters. TFH Publications, Neptune City, NJ. North of Mexico. Houghton Mifflin Company, Boston, MA. 
382 Past Interglacials Working Group of PAGES. 2016. Interglacials of the last 800,000 years.

$383 \quad$ Reviews of Geophysics 54:162-219.

384 Powers, S.L. \& M.L. Warren Jr. 2009. Phylogeography of three snubnose darters (Percidae:

385 Subgenus Ulocentra) endemic to the southeastern US Coastal Plain. Copeia 2009:523-528.

386 Rambaut, A., A.J. Drummond, D. Xie, G. Baele \& M.A. Suchard. 2018. Posterior summarization

387 in Bayesian phylogenetics using Tracer 1.7. Systematic Biology 67:901-904.

388 Rittenour, T.M., M.D. Blum \& R.J. Goble. 2007. Fluvial evolution of the lower Mississippi

389 River Valley during the last 100 k.y. glacial cycle: Response to glaciation and sea-level $390 \quad$ change. GSA Bulletin 119:586-608.

391 Ronquist, F., M. Teslenko, P. van der Mark, D.L. Ayres, A. Darling, S. Höhna, B. Larget, L. Liu, 392 M.A. Suchard \& J.P. Huelsenbeck, J. P. 2012. MrBayes ver. 3.2: efficient Bayesian 393 phylogenetic inference and model choice across a large model space. Systematic 394 biology 61:539-542.

395 Ross, S.T. 2001. Inland Fishes of Mississippi. University Press of Mississippi, Jackson, $396 \quad$ Mississippi. 624 pp.

397 Ruble, C.L., K.A. Sterling \& M.L. Warren Jr. 2019. Captive propagation and early life history of 398 the Yazoo Darter (Etheostoma raneyi). Southeastern Naturalist 18:525-540.

399 Simon, T.P. \& R. Wallus. 2006. Reproductive Biology and Early Life History of Fishes in the 400 Ohio River Drainage, Vol. 4: Percidae- Perch, Pikeperch, and Darters. CRC Press, Boca $401 \quad$ Raton, FL.

402 Smith, D.P., T.H. Diehl, L.A. Turrini-Smith, J. Maas-Baldwin \& Z. Croyle. 2009. River 403 restoration strategies in channelized, low gradient landscapes of West Tennessee, USA. 404 Geological Society of America Special Papers 451:215-229. 
405 Song, C.B., T.J. Near \& L.M. Page. 1998. Phylogenetic relations among percid fishes as inferred 406 from mitochondrial cytochrome $b$ DNA sequence data. Molecular Phylogenetics and 407 Evolution 10:343-353.

408 Stamatakis, A. 2014. RAxML ver. 8: A tool for phylogenetic analysis and post-analysis of large 409 phylogenies. Bioinformatics 30:1312-1313.

410 Sterling, K.A., D.H. Reed, B.P. Noonan \& M.L. Warren, Jr. 2012. Genetic effects of habitat 411 fragmentation and population isolation on Etheostoma raneyi (Percidae). Conservation 412 Genetics 13:859-872.

413 Sterling, K.A., M.L. Warren Jr. \& L.G. Henderson. 2013. Conservation assessment of the Yazoo Darter (Etheostoma raneyi). Southeastern Naturalist 12:816-842.

Suttkus, R.D., R.M. Bailey \& H.L. Bart Jr. 1994. Three new species of Etheostoma, subgenus Ulocentra, from the Gulf Coastal Plain of Southeastern United States. Tulane Studies in Zoology and Botany 29:97-126.

418

Turner, T.F. \& J.C Trexler. 1998. Ecological and historical associations of gene flow in darters (Teleostei: Percidae). Evolution 52:1781-1801.

Turner, T.F. 2001. Comparative study of larval transport and gene flow in darters. Copeia 2001: $766-774$.

USDA Forest Service. 2013. Forest Service designated sensitive species on the National Forests and Grasslands. Available at: https://www.fs.fed.us/biology/resources/pubs/tes/fs_ss_310ct05.pdf. Accessed October 2018.

Warren, M.L., Jr., B.M. Burr, S.J. Walsh, H.L. Bart Jr., R.C. Cashner, D.A. Etnier, B.J. Freeman, B.R. Kuhajda, R.L. Mayden, H.W. Robison, S.T. Ross \& W.C. Starnes. 2000. Diversity, 
428 distribution, and conservation status of the native freshwater fishes of the southern United 429 States. Fisheries 25:7-29.

430 Warren, M.L., Jr., W.R. Haag \& S.B. Adams. 2002. Forest linkages to diversity and abundance 431 in lowland stream fish communities. In: M.M. Holland, M.L. Warren, Jr. \& J.A. Stanturf 432 (Eds.). Proceedings of a conference on sustainability of wetlands and water resources: how 433 well can riverine wetlands continue to support society into the 21st century?, pp 168-182. 434 USDA Forest Service, Southern Research Station, General Technical Report SRS-50, 435 Asheville, N.C. 
Figure 1

Distribution of snubnose darters among lower Mississippi River drainages of Kentucky, Tennessee, and Mississippi (southeastern United States).

Major river systems and physiographic provinces discussed in the text are shown; abbreviations are defined as: L.T. $=$ Little Tallahatchie, M.A.P. $=$ Mississippi Alluvial Plain, L.G.C.P. $=$ Lower Gulf Coastal Plain, U.G.C.P. = Upper Gulf Coastal Plain. 


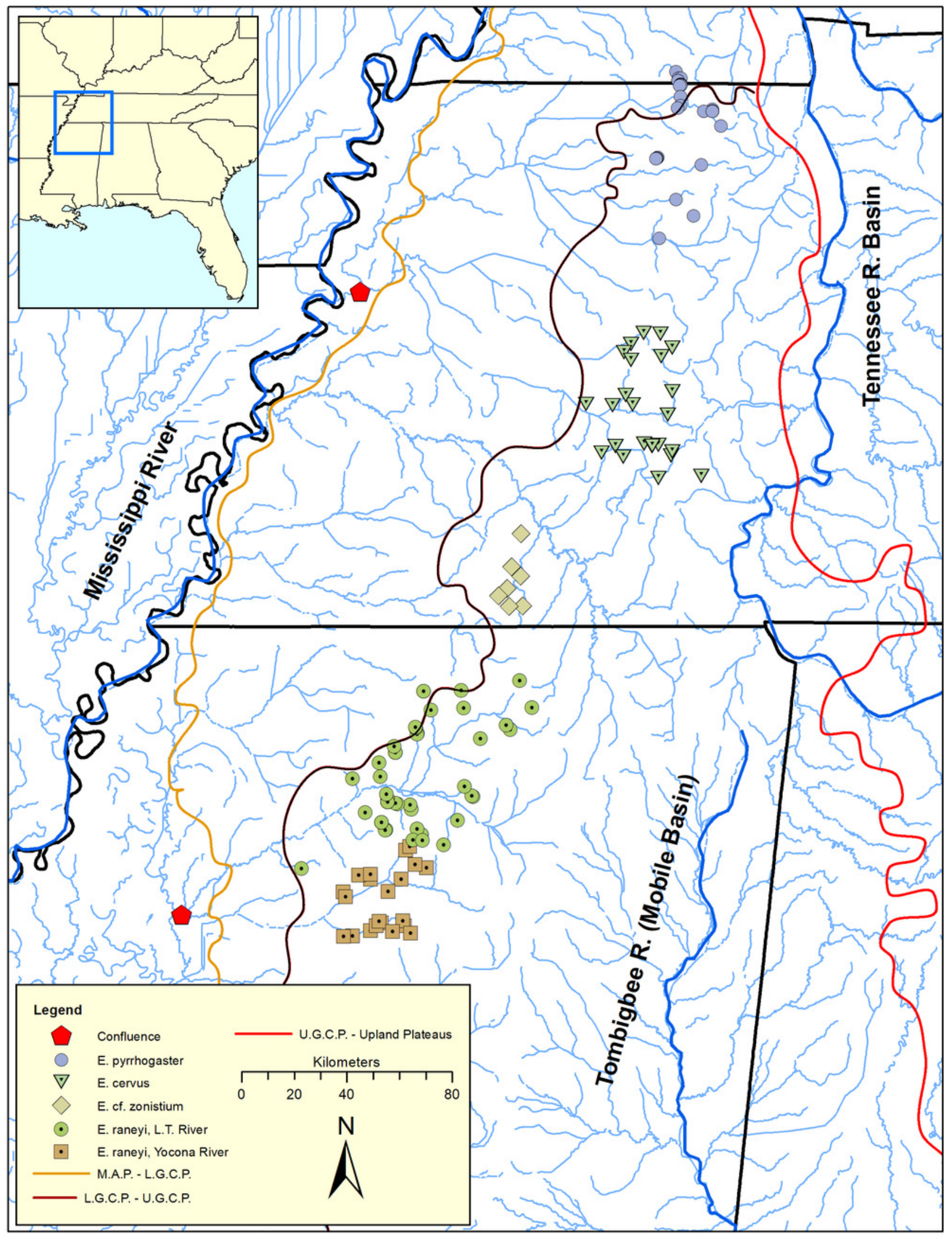


Figure 2

Map showing genetic tissue sample sites for Yazoo Darters in the Little Tallahatchie River drainage (blue) and Yocona River drainage (red).

Names of watersheds used for genetic distance estimates (see Table 3) and discussed in the text are also shown. Numbers correspond to data in Table 1; Y.R. = Yocona River, L.T.R. = Little Tallahatchie River.

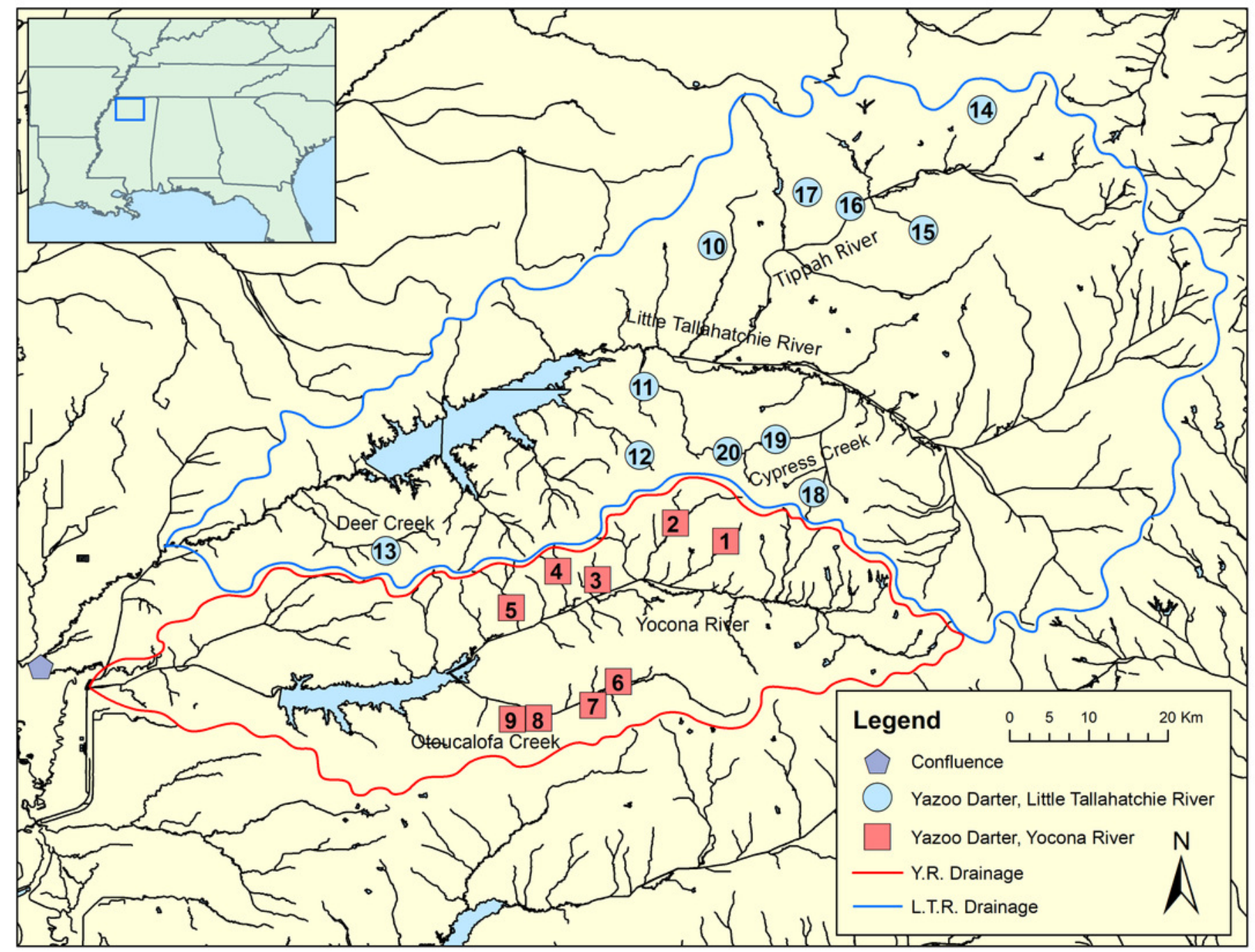


Figure 3

Phylogenetic tree of the partitioned cytb dataset using Bayesian estimation (MrBayes ver. 3.2.6).

Bayesian posterior probabilities $\geq 0.95$ are shown (except for the Yocona River clade) at the nodes (see Table S1 for sequence data); bubble sizes for the pruned nodes are proportional to sample size; L.T.R. = Little Tallahatchie River drainage, Y.R. = Yocona River drainage.

P. sciera

E. nigrum

1.0

Yazoo Darter, L.T.R.

Tree scale: 0.01

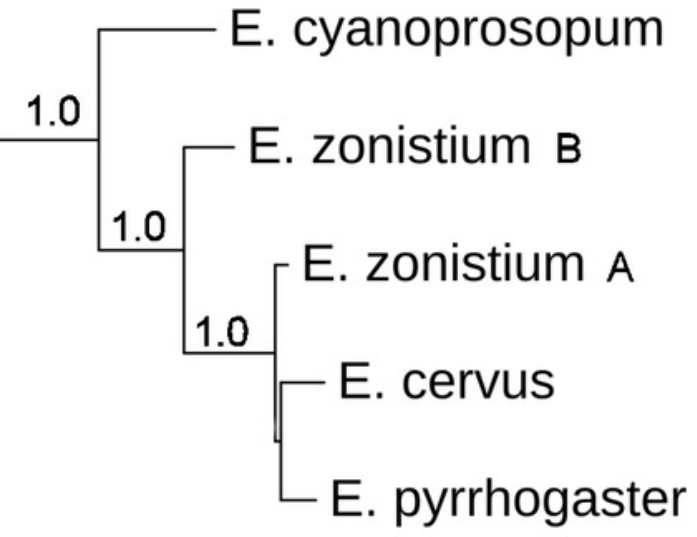


Figure 4

Phylogenetic tree of the partitioned $c y t b$ dataset using maximum likelihood estimation (RAXML-HPC ver. 8.0).

Bootstrap values $\geq 95$ are shown at the nodes (see Table S1 for sequence data); bubble sizes for the pruned nodes are proportional to sample size; L.T.R. = Little Tallahatchie River drainage, Y.R. = Yocona River drainage.

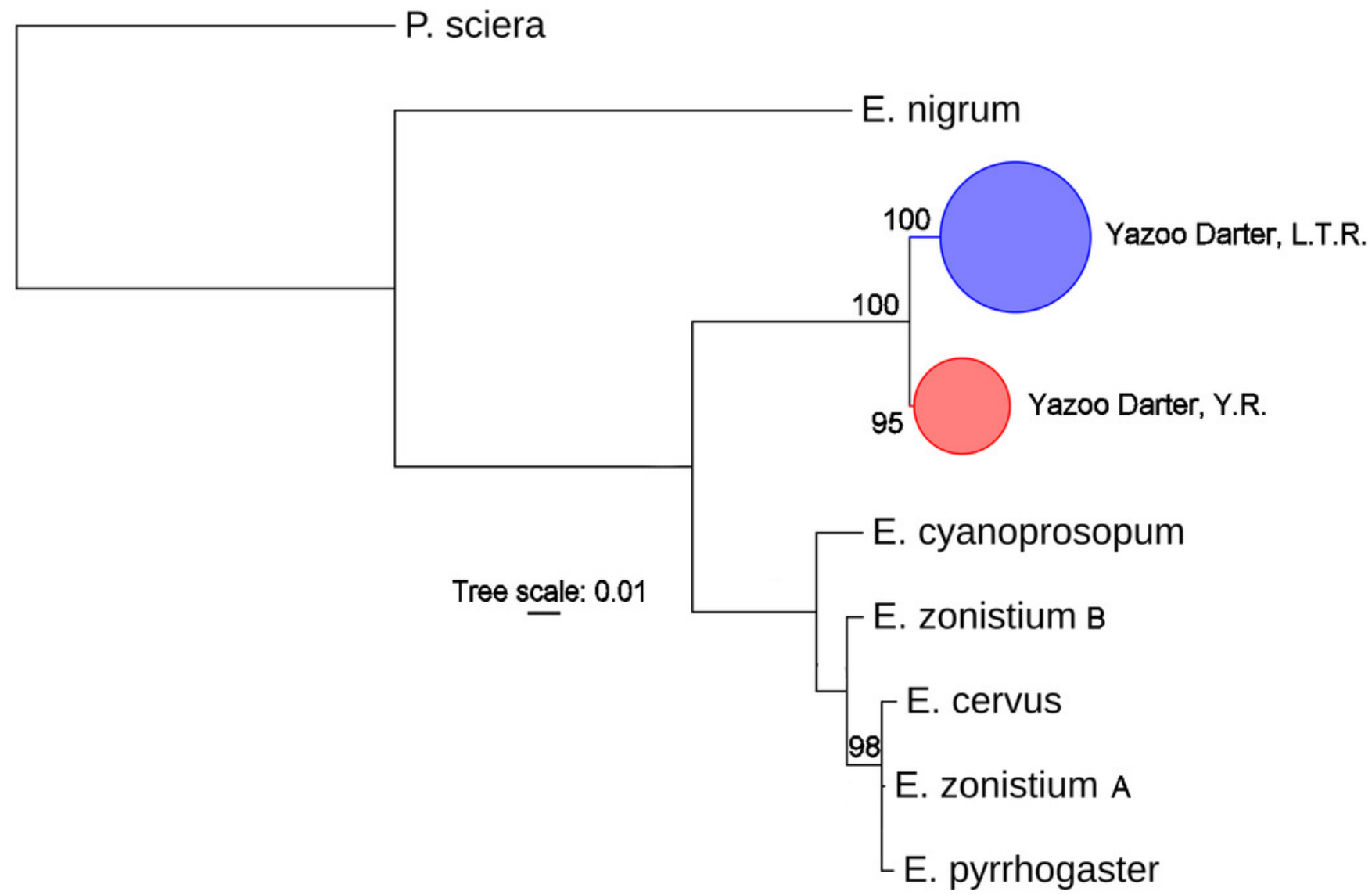


Figure 5

Phylogenetic tree of the partitioned S7 dataset using Bayesian estimation (MrBayes ver. 3.2.6).

Bayesian posterior probabilities $\geq 0.95$ are shown at the nodes (see Table S2 for sequence data); bubble sizes for the pruned nodes are proportional to sample size; L.T.R. = Little Tallahatchie River drainage, Y.R. = Yocona River drainage.

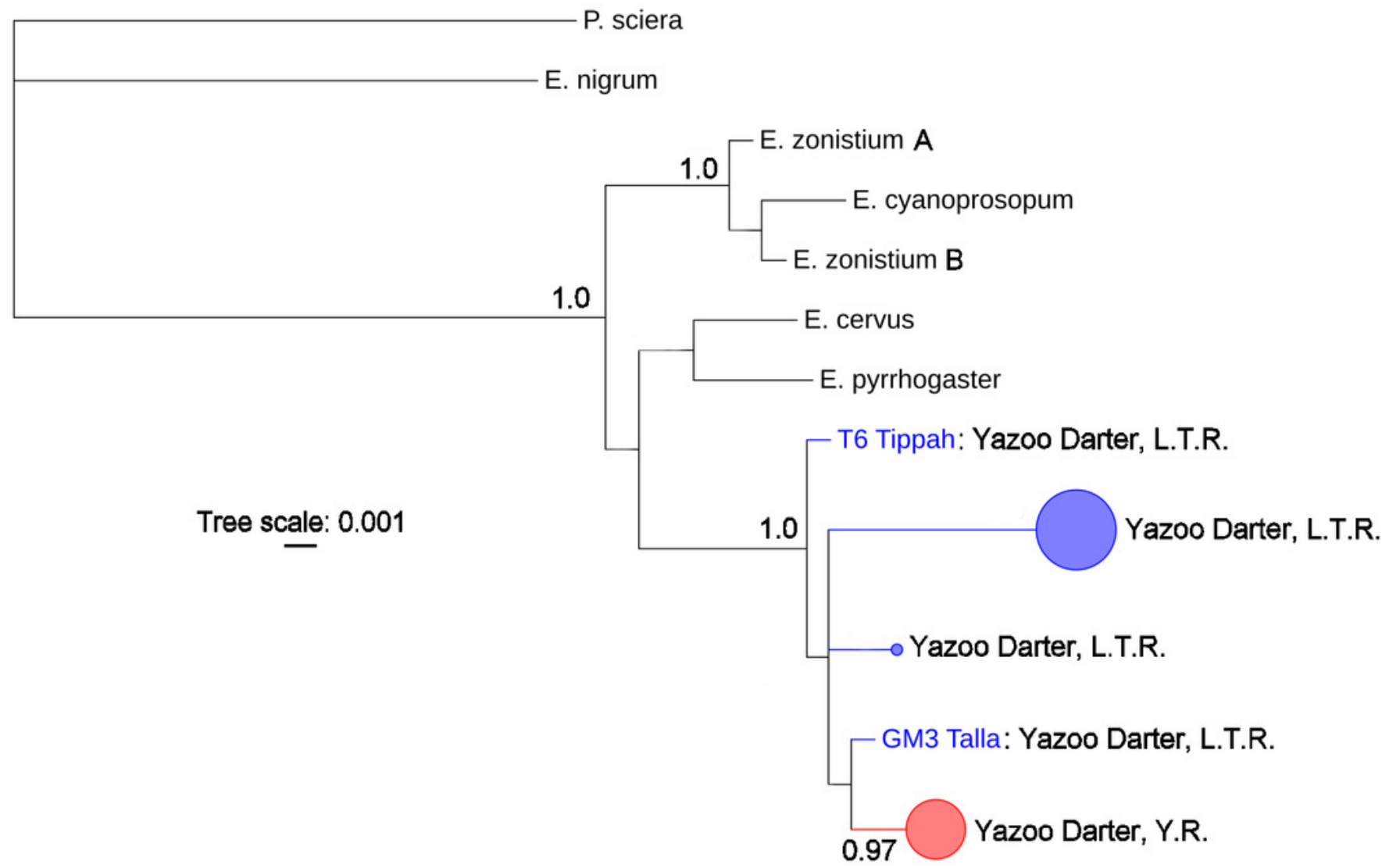


Figure 6

Phylogenetic tree of the partitioned S7 dataset using maximum likelihood estimation (RAXML-HPC ver. 8.0).

Bootstrap values $\geq 95$ are shown at the nodes (see Table S2 for sequence data); bubble sizes for the pruned nodes are proportional to sample size; L.T.R. = Little Tallahatchie River drainage, Y.R. = Yocona River drainage.

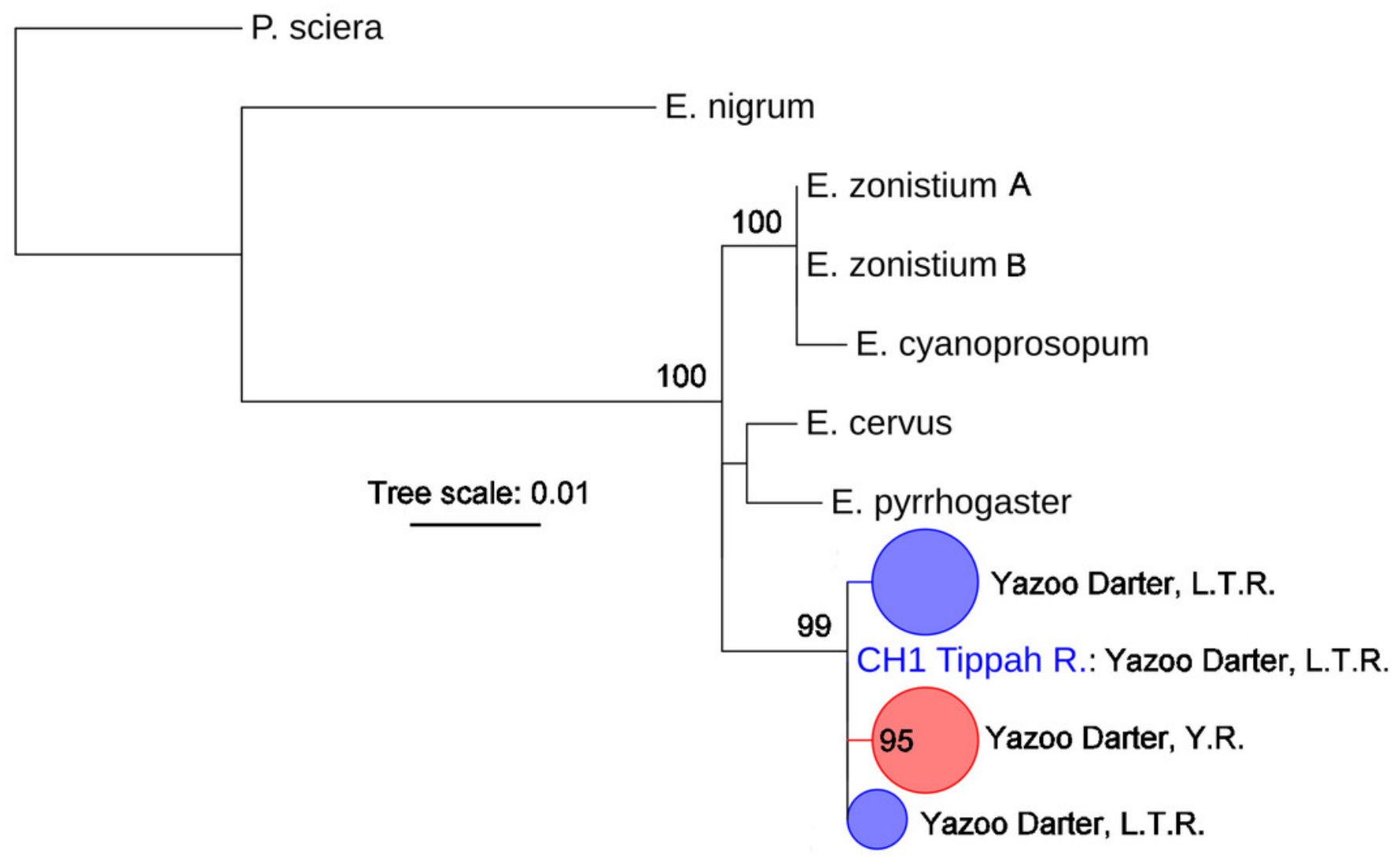


Figure 7

S7 (A) and cytb (B) haplotype networks for samples among the Little Tallahatchie and Yocona River drainages, and watersheds (e.g.,Cypress Creek) within drainages (see Fig. 2).

Red and blue indicates the Yocona and Little Tallahatchie river drainages, respectively.

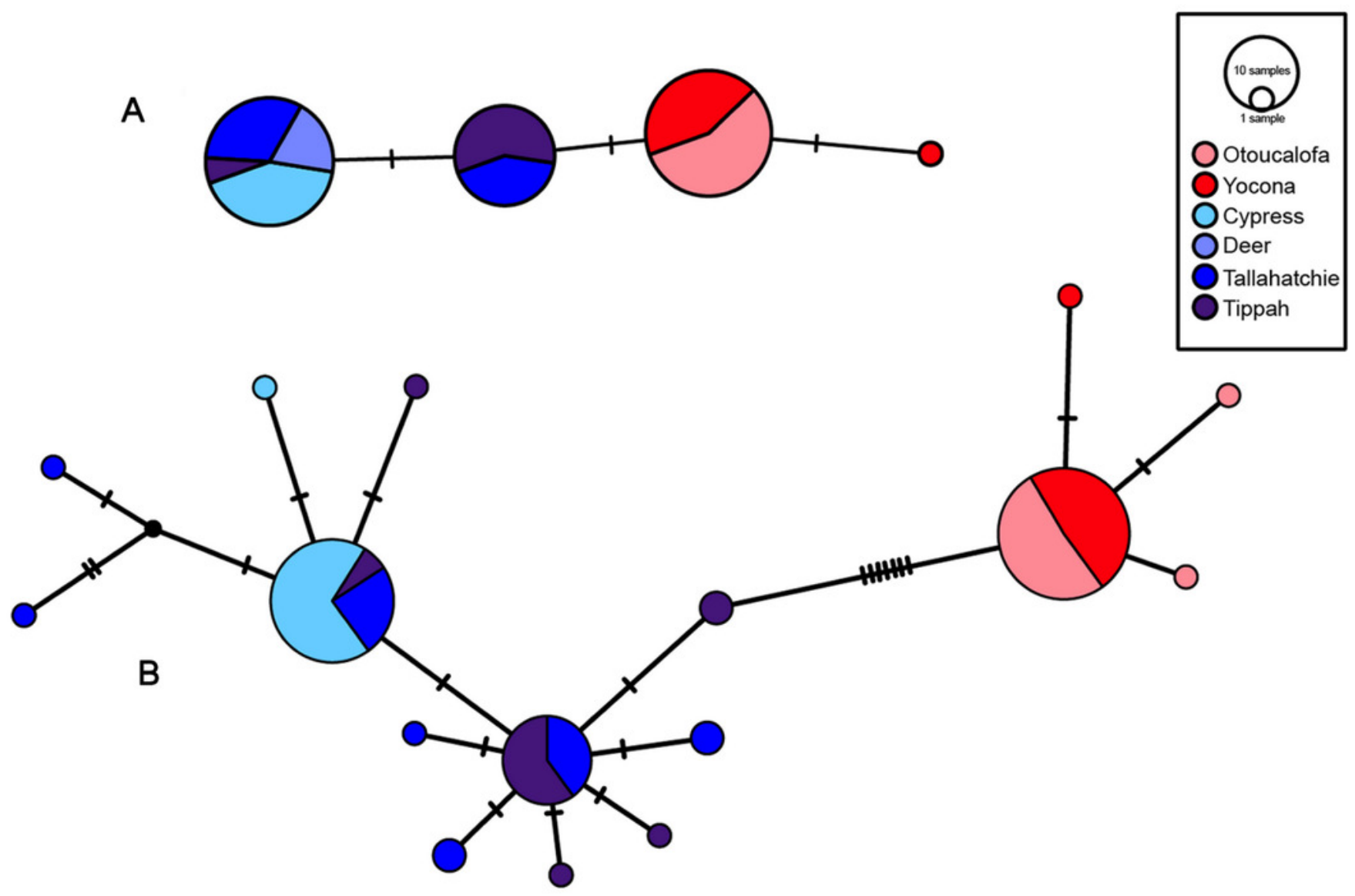




\section{Table $\mathbf{1}$ (on next page)}

Genetic tissue sample data for each of the two major drainages within the distribution of the Yazoo Darter.

Sample locations, drainage, and sample sizes for genetic analyses are shown. Site ID numbers correspond to Fig. 2; see Tables S1 and S2; U.T. = unnamed tributary. 


\begin{tabular}{|c|c|c|c|c|c|c|}
\hline Site ID & Drainage & Stream & Cytb, n & $S 7, \mathrm{n}$ & Latitude & Longitude \\
\hline 1 & Yocona River & Pumpkin Creek & 4 & 1 & 34.327 & -89.398 \\
\hline 2 & Yocona River & Yellow Leaf Creek & 2 & 1 & 34.348 & -89.455 \\
\hline 3 & Yocona River & Morris Creek & 4 & 4 & 34.283 & -89.544 \\
\hline 4 & Yocona River & Taylor Creek & 5 & 5 & 34.293 & -89.589 \\
\hline 5 & Yocona River & Splinter Creek & 3 & 4 & 34.251 & -89.642 \\
\hline 6 & Yocona River & Mill Creek & 6 & 6 & 34.167 & -89.52 \\
\hline 7 & Yocona River & Gordon Branch & 3 & 2 & 34.14 & -89.549 \\
\hline 8 & Yocona River & U.T. Otoucalofa Creek & 4 & 3 & 34.125 & -89.611 \\
\hline 9 & Yocona River & Johnston Creek & 6 & 6 & 34.124 & -89.641 \\
\hline 10 & Little Tallahatchie River & Big Spring Creek & 10 & 13 & 34.664 & -89.413 \\
\hline 11 & Little Tallahatchie River & Graham Mill Creek & 3 & 3 & 34.503 & -89.491 \\
\hline 12 & Little Tallahatchie River & Hurricane Creek & 2 & 3 & 34.425 & -89.496 \\
\hline 13 & Little Tallahatchie River & Deer Creek & 6 & 6 & 34.316 & -89.785 \\
\hline 14 & Little Tallahatchie River & Yellow Rabbit Creek & 5 & 4 & 34.819 & -89.106 \\
\hline 15 & Little Tallahatchie River & Chilli Creek & 5 & 4 & 34.682 & -89.173 \\
\hline 16 & Little Tallahatchie River & U.T. Tippah River & 2 & 2 & 34.709 & -89.256 \\
\hline 17 & Little Tallahatchie River & Chewalla Creek & 4 & 3 & 34.725 & -89.305 \\
\hline 18 & Little Tallahatchie River & Cypress Creek & 7 & 6 & 34.382 & -89.298 \\
\hline 19 & Little Tallahatchie River & Puskus Creek & 12 & 6 & 34.443 & -89.341 \\
\hline 20 & Little Tallahatchie River & Bay Springs Branch & 2 & 1 & 34.429 & -89.396 \\
\hline
\end{tabular}




\section{Table 2 (on next page)}

Genetic characters that diagnose allopatric populations of Yazoo Darters in the Little Tallahatchie (L.T.R.) and Yocona rivers (Y.R.) using mitochondrial cytochrome b (cytb) and nuclear $S 7$ genes.

Numbers indicate the location of the character along the genetic sequence; $\mathrm{A}=$ adenine, $\mathrm{C}=$ cytosine, $T$ = thymine, $G=$ guanine. 
1

\begin{tabular}{ccc}
\hline Character (cytb) & L.T.R. & Y.R. \\
\hline 147 & $\mathrm{~A}$ & $\mathrm{G}$ \\
165 & $\mathrm{C}$ & $\mathrm{T}$ \\
585 & $\mathrm{C}$ & $\mathrm{T}$ \\
588 & $\mathrm{~T}$ & $\mathrm{C}$ \\
654 & $\mathrm{~A}$ & $\mathrm{G}$ \\
876 & $\mathrm{G}$ & $\mathrm{A}$ \\
897 & $\mathrm{~A}$ & $\mathrm{G}$ \\
930 & $\mathrm{G}$ & $\mathrm{A}$ \\
1056 & $\mathrm{~A}$ & $\mathrm{G}$ \\
1090 & $\mathrm{G}$ & $\mathrm{A}$ \\
1107 & $\mathrm{G}$ & $\mathrm{A}$ \\
1113 & $\mathrm{G}$ & $\mathrm{A}$ \\
\hline Character (S7) & L.T.R. & Y.R. \\
\hline 286 & $\mathrm{G}$ & $\mathrm{A}$ \\
insertion: 478 & $\mathrm{G}$ & - \\
insertion: 479 & $\mathrm{C}$ & -
\end{tabular}

2 


\section{Table 3(on next page)}

Uncorrected pairwise genetic distances (p-distance, \%) among watersheds for Yazoo Darters.

Values for cytb are below the diagonal and for $S 7$ are above the diagonal; abbreviations are defined in the table. 
1

\begin{tabular}{lccccc}
\hline & Otoucalofa Cr. & Y.R. & L.T.R. & Tippah R. & Cypress Cr. \\
\hline Otoucalofa Creek & & 0.01 & 0.35 & 0.24 & 0.41 \\
Yocona River & 0.01 & & 0.36 & 0.25 & 0.43 \\
Little Tallahatchie River & 0.82 & 0.81 & & 0.13 & 0.07 \\
Tippah River & 0.76 & 0.75 & 0.11 & & 0.17 \\
Cypress Creek & 0.83 & 0.82 & 0.10 & 0.10 &
\end{tabular}

2 


\section{Table 4 (on next page)}

Uncorrected pairwise genetic distances (p-distances, \%), among snubnose darters that are most closely related to the Yazoo Darter (Near et al., 2011).

Species complexes are grouped following Near et al. (2011); labels for undescribed species follows Jelks et al. (2008). Bold type and asterisk = values <2.0\%; L.T.R. $=$ Yazoo Darter, Little Tallahatchie River drainage, Y.R. $=$ Yazoo Darter, Yocona River drainage, Fk. = Fork, Cr. = creek; see Table S3 for complete results. 


\begin{tabular}{|c|c|c|c|c|c|c|c|}
\hline & \multicolumn{2}{|c|}{ E. raneyi (Yazoo Darter group) } & \multicolumn{5}{|c|}{ E. zonistium (Bandfin Darter group) } \\
\hline & Y.R. & L.T.R. & E.zonistium & E. cf. zonistium & E. cervus & $\begin{array}{c}\text { E. } \\
\text { pyrrhogaster }\end{array}$ & E. cyanoprosopum \\
\hline \multicolumn{8}{|l|}{ Y.R. } \\
\hline L.T.R. & $0.75^{*}$ & & & & & & \\
\hline E. zonistium & 7.61 & 8.07 & & & & & \\
\hline E. cf. zonistium & 8.33 & 8.64 & $1.29^{*}$ & & & & \\
\hline E. cervus & 8.45 & 8.97 & $1.42^{*}$ & $0.50 *$ & & & \\
\hline E. pyrrhogaster & 8.61 & 9.04 & $1.44^{*}$ & $0.72^{*}$ & $0.86^{*}$ & & \\
\hline E. cyanoprosopum & 8.84 & 9.24 & 4.25 & 4.75 & 4.86 & 4.84 & \\
\hline E. bellator & 8.50 & 8.99 & 8.93 & 9.38 & 9.48 & 9.39 & 9.84 \\
\hline E. chermocki & 8.22 & 8.71 & 8.74 & 9.19 & 9.29 & 9.20 & 9.62 \\
\hline "Locust Fork" & 9.70 & 10.18 & 9.64 & 9.81 & 9.80 & 9.81 & 10.24 \\
\hline "Sipsey" & 10.29 & 10.40 & 10.69 & 11.02 & 10.99 & 10.84 & 11.02 \\
\hline "Conasauga" & 8.79 & 8.71 & 9.03 & 9.32 & 9.41 & 9.46 & 9.51 \\
\hline "Amicalola" & 7.84 & 7.95 & 7.78 & 8.08 & 8.17 & 8.41 & 8.20 \\
\hline E. brevirostrum & 8.79 & 8.71 & 9.22 & 9.51 & 9.60 & 9.68 & 9.78 \\
\hline E. simoterum & 14.33 & 14.24 & 15.03 & 15.01 & 15.04 & 15.42 & 15.01 \\
\hline \multirow[t]{3}{*}{ Percina sciera } & 16.91 & 16.81 & 16.81 & 17.30 & 17.46 & 17.47 & 17.11 \\
\hline & \multicolumn{4}{|c|}{ E. bellator (Warrior Darter group) } & \multicolumn{3}{|c|}{ E. brevirostrum (Holiday Darter group) } \\
\hline & E. bellator & E. chermocki & "Locust Fk." & "Sipsey" & "Conasauga" & "Amicalola" & E. brevirostrum \\
\hline \multicolumn{8}{|l|}{ E. bellator } \\
\hline E. chermocki & $0.57^{*}$ & & & & & & \\
\hline "Locust Fork" & 5.11 & 4.92 & & & & & \\
\hline "Sipsey" & 6.24 & 6.05 & 6.57 & & & & \\
\hline "Conasauga" & 8.79 & 8.60 & 9.22 & 9.84 & & & \\
\hline "Amicalola" & 7.45 & 7.07 & 7.69 & 8.21 & 3.15 & & \\
\hline E. brevirostrum & 8.88 & 8.69 & 9.89 & 10.12 & $1.05^{*}$ & 3.63 & \\
\hline E. simoterum & 14.33 & 14.14 & 13.90 & 14.52 & 14.90 & 13.94 & 14.71 \\
\hline Percina sciera & 15.85 & 15.57 & 15.62 & 17.03 & 17.77 & 17.00 & 17.86 \\
\hline
\end{tabular}

